\title{
Latewood Ring Width Reveals CE 1734 Felling Dates for Walker House Timbers in Tupelo, Mississippi, USA
}

\author{
Thomas W. Patterson ${ }^{1} * *^{(D)}$, Grant L. Harley ${ }^{2}$ (D) David H. Holt ${ }^{1}$, Raymond T. Doherty ${ }^{3}$, Daniel J. King ${ }^{2}$, \\ Karen J. Heeter ${ }^{2}{ }^{\infty}$, Ashley L. Chasez ${ }^{1}$, Alyssa C. Crowell ${ }^{1}$ and Ian M. Stewart ${ }^{1}$ \\ 1 School of Biological, Environmental and Earth Sciences, The University of Southern Mississippi, \\ Hattiesburg, MS 39406, USA; David.H.Holt@usm.edu (D.H.H.); Ashley.Chasez@usm.edu (A.L.C.); \\ Alyssa.Crowell@usm.edu (A.C.C.); Ian.Stewart@usm.edu (I.M.S.) \\ 2 Department of Earth and Spatial Sciences, University of Idaho, Moscow, ID 83844, USA; \\ gharley@uidaho.edu (G.L.H.); djking@uidaho.edu (D.J.K.); kheeter@uidaho.edu (K.J.H.) \\ 3 Department of Sociology and Anthropology, The University of Mississippi, Oxford, MS 38677, USA; \\ dohray@gmail.com \\ * Correspondence: thomas.w.patterson@usm.edu; Tel.: +1-601-266-6077
}

check for updates

Citation: Patterson, T.W.; Harley, G.L.; Holt, D.H.; Doherty, R.T.; King, D.J.; Heeter, K.J.; Chasez, A.L.;

Crowell, A.C.; Stewart, I.M.

Latewood Ring Width Reveals CE 1734 Felling Dates for Walker House Timbers in Tupelo, Mississippi, USA. Forests 2021, 12, 670. https:/ / doi.org/10.3390/f12060670

Academic Editor: Daniele Castagneri

Received: 31 March 2021

Accepted: 17 May 2021

Published: 25 May 2021

Publisher's Note: MDPI stays neutral with regard to jurisdictional claims in published maps and institutional affiliations.

Copyright: (C) 2021 by the authors. Licensee MDPI, Basel, Switzerland. This article is an open access article distributed under the terms and conditions of the Creative Commons Attribution (CC BY) license (https:// creativecommons.org/licenses/by/ $4.0 /)$.

\begin{abstract}
Dendroarchaeology is under-represented in the Gulf Coastal Plain region of the United States (US), and at present, only three published studies have precision dated a collection of 18th-19thcentury structures. In this study, we examined the tree-ring data from pine, poplar, and oak timbers used in the Walker House in Tupelo, Mississippi. The Walker House was constructed ca. the mid1800 s with timbers that appeared to be recycled from previous structures. In total, we examined 30 samples (16 pines, 8 oaks, and 6 poplars) from the attic and crawlspace. We cross-dated latewood ring growth from the attic pine samples to the period 1541-1734 $(r=0.52, t=8.43, p<0.0001)$ using a 514-year longleaf pine (Pinus palustris Mill.) latewood reference chronology from southern Mississippi. The crawlspace oak samples produced a 57-year chronology that we dated against a white oak (Quercus alba L.) reference chronology from northeast Alabama to the period 1765-1822 $(r=0.36, t=2.83, p<0.01)$. We were unable to cross-date the six poplar samples due to a lack of poplar reference chronologies in the region. Our findings have two important implications: (1) the pine material dated to 1734 represents the oldest dendroarchaeology-confirmed dating match for construction materials in the southeastern US, and (2) cross-dating latewood growth for southeastern US pine species produced statistically significant results, whereas total ring width failed to produce significant dating results.
\end{abstract}

Keywords: dendroarchaeology; tree-ring; Chickasaw; longleaf pine; cross-dating

\section{Introduction}

When the age of a historical structure is unknown due to a lack of documentary records, applications of tree-ring science (i.e., dendroarchaeology) can provide accurate information regarding the harvest dates for timbers used in these structures. These harvest dates establish an earliest possible date of construction and provide evidence to estimate the true age of a structure [1]. Precision dating of historic structures in the southeastern United States (US) has flourished in the last decade [2-11]. Within this region, the Gulf Coastal Plain remains under-represented aside from three published studies [12-14].

Dendroarchaeology in the Gulf Coastal Plain is challenging due to the natural factors of wood preservation. The Gulf Coastal Plain region is located within the humid subtropics (ca. $30-35^{\circ} \mathrm{N}$ ) and supports $1.3-1.8 \mathrm{~m}$ of annual precipitation $[15,16]$. Concurrently, the Gulf Coastal Plain region hosts the highest density of wood-destroying termites in the US [17]. Furthermore, species-specific reference chronologies, against which remnant timbers are cross-dated, are sporadic along the Gulf Coastal Plain region [18], and multicentury reference chronologies are typically limited to mesic and wetland species. However, 
recent advances in applying techniques of dendrochronology to tree species in the Gulf Coast region have increased the number of dated structures. For example, timbers in the La-Pointe Krebs House in Pascagoula, Mississippi were dated to 1757 CE [13], and the Deason House in Ellisville, Mississippi was dated to 1835 CE [12] using longleaf pine (Pinus palustris Mill.). Further, the Le Citron Bistro/Old Jesuit Plantation in New Orleans, Louisiana, was dated to 1762 CE [14] using bald cypress (Taxodium distichum L. (Rich.).

\section{History of the Colbert-Walker Site}

The Colbert-Walker site (22Le1048) near Tupelo, Mississippi, has a complex cultural history that archaeological excavations have shown to have had multiple periods of occupation [19]. The site hosts a single-story Greek-Revival style home that was built by the Walker family prior to the US Civil War, most likely in the mid-1850s (hereafter Walker House). Recent archaeological excavations uncovered a pre-existing brick foundation underneath the footprint of the Walker House (Figure 1A), and timbers from the attic display multiple methods of conversion that include hand-hewn, hand-sawn, and circular-sawn surfaces (Figure 1B; [19]). All 29 of the poplar joists in the attic are the exact length $(5.59 \mathrm{~m})$ as the depth (front to back) of the pre-existing brick foundation. Many of these joists have the vestigial floorboards and ceiling board nails that were commonly used between 1812 and 1825 [20]. These joists would have been distributed as ceiling joists across the $14.6 \mathrm{~m}$ width of the earlier structure [19]. Underneath the Walker House are split-log oak floor joists, many retaining their bark (Figure 1C), which had already been determined to be from a different, more crudely built structure, such as a barn or other outbuilding.



Figure 1. Walker House (A) pre-existing brick foundation, (B) hand-finished attic timbers, and (C) crawlspace oak joists. Photos by R. Doherty. 
One theory as to the origin of the subterranean foundation (Figure 1C) leads to George Colbert and the Chickasaw Council House. According to historical Works Progress Administration documents, Chickasaw leader George Colbert raised a structure along the Natchez Trace that served as the national council house for the Chickasaw Nation, and later as a tavern for travelers on the road linking Natchez, Mississippi to Nashville, Tennessee [21]. More importantly, the newly built national council house hosted the Convention of Southern Tribes, attended by over 75 headmen of the Chickasaw, Cherokee, and Choctaw nations [19]. With Andrew Jackson representing the US, the meeting concluded with the signing of the 1816 Treaty of the Chickasaw Council House. Colbert's location has appeared in maps near modern-day Tupelo as early as 1814, establishing it as a significant and noteworthy destination at the intersection of the Natchez Trace and other travel routes (Figure 2).

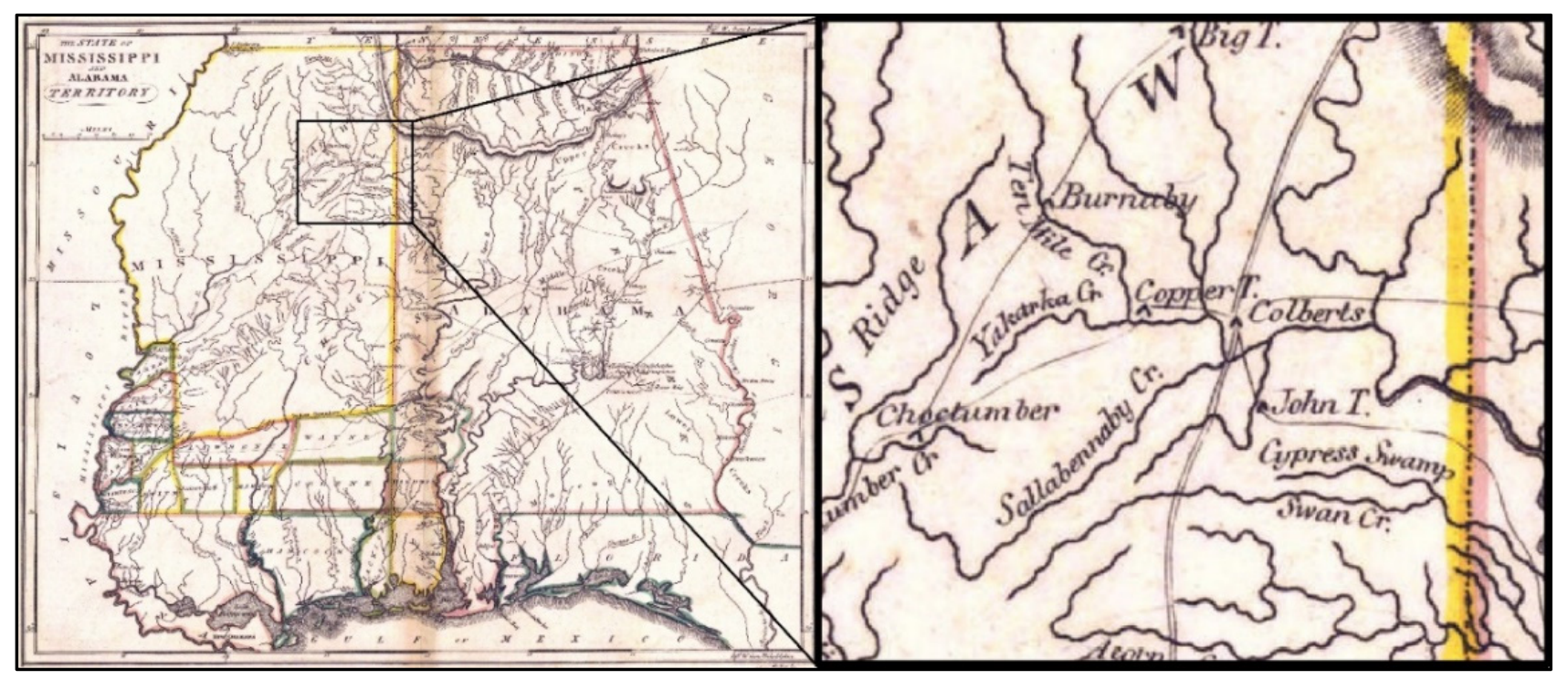

Figure 2. 1814 map of Mississippi and Alabama [22] showing "Colberts" near modern-day Tupelo where several trade paths meet (center of inset map).

In this study, we examined the tree-ring data from timbers in the Walker House to determine if they were recycled from the Chickasaw Council House when the Walkers constructed their home. We initially hypothesized that the outer years of timbers in the Walker House should cluster around two important dates. First, if timbers were recycled from the Chickasaw Council House, we expected to find the felling dates to align ca. 1814-1815. Second, if the Walkers built their home mid-19th century, we expected a second set of felling dates to align ca. the 1850s. The following details our investigation into these hypotheses, as well as the importance of our findings for future dendroarcheological studies in the Gulf Coastal Plain region.

\section{Materials and Methods}

\subsection{Field Methods}

We began by scouting the attic and crawlspace for suitable timbers that displayed hallmarks of an outer growth year (e.g., remnant bark, beetle galleries, patina from exposure, etc.), ensuring that the harvest year remained intact in the outermost, final growth ring in each sample. To obtain samples from these timbers, we used both reciprocating saws and drills with custom-made $12 \mathrm{~mm}$ dendroarchaeology bits. Where we were able to use the reciprocating saw, such as on timber ends that were non-load bearing, we removed approximately $2.5 \mathrm{~cm}$ thick sections. Using this method allowed us to extract the maximum number of rings. On the other timbers, we used the hollow drill bits to remove $12 \mathrm{~mm}$ diameter samples, which varied in length depending on the size of the timber sampled. In the crawlspace, we sampled exposed floor joists using the reciprocating saw and drill 
bit. All crawlspace joists displayed an outer edge (most retaining bark), so we selected the largest of these timbers toward sampling the maximum number of rings. Next, we glued all cores into wooden mounts for secure transport back to the laboratory and coded all samples based on cardinal direction.

\subsection{Laboratory Methods}

In the laboratory, we prepared samples for analysis using standard procedures [1]. We scanned all samples at a resolution of 1200 dots per square inch using a flatbed Epson scanner and measured them with the computer program CooRecorder [23]. In CooRecorder, we drew a digital path perpendicular to each tree-ring and measured each growth ring with $0.01 \mathrm{~mm}$ accuracy. We delineated annual tree-ring width (hereafter total width) and intra-annual season wood (hereafter earlywood and latewood). We compiled samples from each species into floating (i.e., not anchored in time) chronologies using C-Dendro [23], then cross-dated each sample into one master chronology using the program COFECHA [24]. The result of this cross-dating process was that we accurately aligned contemporaneous rings from each sample (i.e., highest $r$ value, fewest cross-dating problems).

We developed species-specific chronologies using the program ARSTAN $[25,26]$ to produce composite-site chronologies that we named for each species from the structure. Our preliminary assessment grouped the samples into three species/genera: oak (Quercus spp.), tulip poplar (Liriodendron tulipifera L.), and pine (Pinus spp.) [27]. Once we established our species chronologies, we then began to date the material against reference tree-ring chronologies in the region. The International Tree-Ring Databank [28] provides access to established tree-ring chronologies across the US, and we downloaded all chronologies within a $500 \mathrm{~km}$ radius of Tupelo, Mississippi that matched the wood species/genus identified in the structure. For the pine chronology, we exclusively used latewood for cross-dating due to the higher degree of interannual variability relative to earlywood and total width (Figure $3 ;[29,30])$. We used the total width for the oak and poplar chronologies, as seasonally-resolved reference chronologies were unavailable at the time of this study.

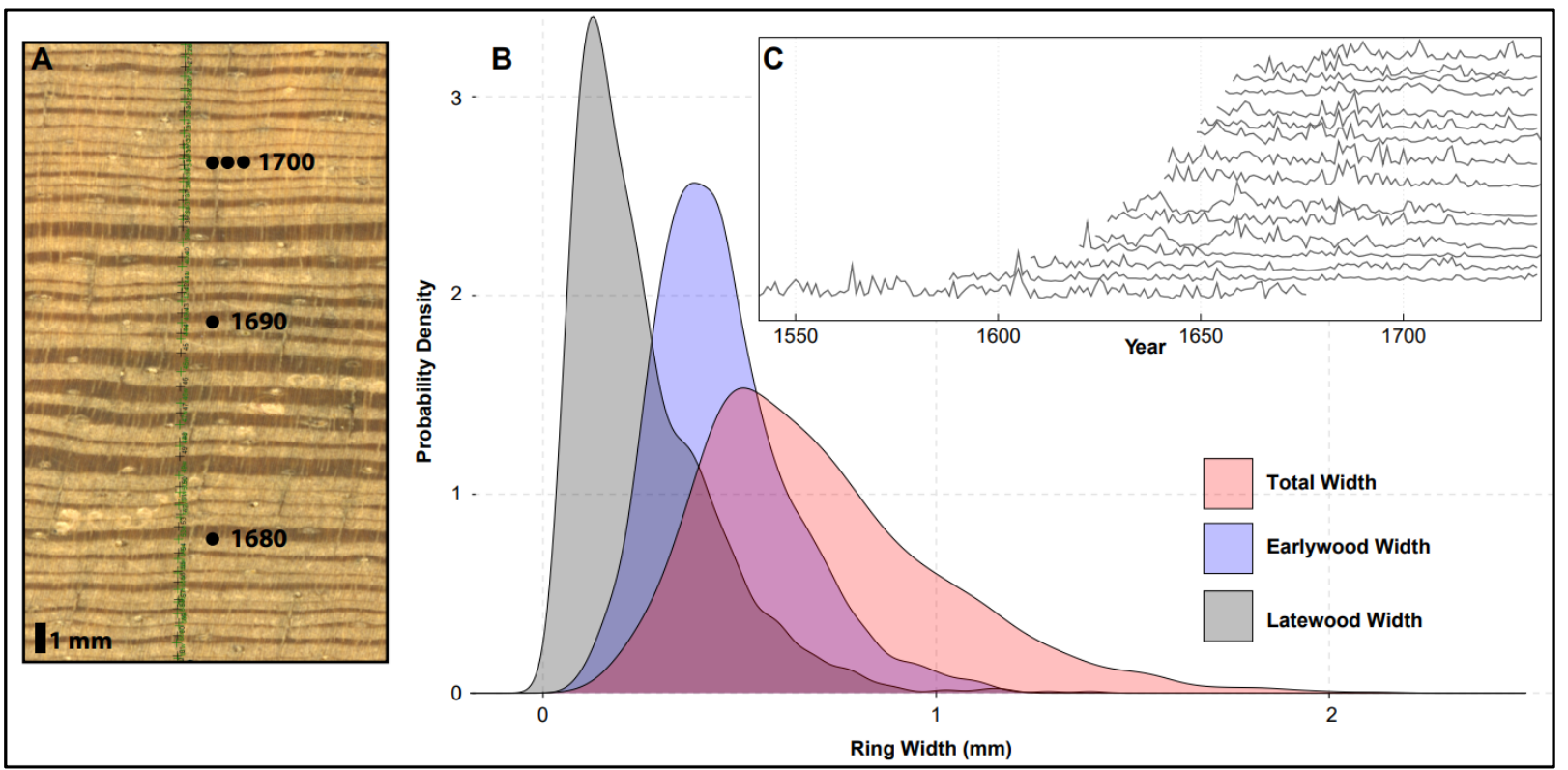

Figure 3. Walker House Pinus spp. ring-width measurement differences. (A) Scanned image example of sample DK3 showing measurement path (black and green + ), decadal dates, and visual differences in total width, earlywood, and latewood width variability. (B) Probability density functions of all total width, earlywood, and latewood widths ( $n=1552)$ measured in Pinus spp. samples extracted from Walker House timbers. (C) Spaghetti plot of latewood widths from the 16 Walker House Pinus spp. samples. 
The final step was to cross-date each species chronology against their respective reference chronologies with the program COFECHA [24]. COFECHA performs correlations of each floating chronology against the reference chronology for every possible fit (an iterative process that runs hundreds of scenarios) and provides statistics that indicate the strongest placement for absolute dating. Once we evaluated each date placement suggested by COFECHA with additional visual diagnostics in Microsoft Excel, we assigned years to each Walker House chronology and provided harvest dates for the timbers used in the structure.

\section{Results}

\subsection{Species Identification and Chronology Development}

In total, we collected 23 samples from the attic and 14 samples from the crawlspace of the Walker House. In the attic, 15 samples were pine and 8 were poplar. Twelve samples from the crawlspace were oak, one sample was pine, and one sample was bald cypress. Zero samples from the attic contained pith or near-pith curvature; however, two oak samples from the crawlspace contained near-pith curvature, and the cypress sample contained pith (excluded from analysis). Due to poor statistical fit $(r<0.33, p>0.01)$, some of these samples did not advance through statistical cross-dating, and therefore, we omitted them from future analyses. In total, 15 pine samples advanced into the final attic pine chronology, 6 poplar samples advanced into the final attic poplar chronology, and 8 oak samples advanced into the final crawlspace oak chronology. The one pine sample from the crawlspace cross-dated to the attic pine chronology, indicating that this sample was from the same source as the pine timbers in the attic. We included this sample with the attic pine chronology, bringing its total sample size to 16.

After extensive testing, we found that two reference chronologies matched the hypothesized species, and we used these reference chronologies for all analyses. The reference chronology that we used to date the crawlspace oak samples was a white oak (Quercus alba L.) chronology, produced from the Sipsey Wilderness, that spans the period 1679-1985 [31]. The second chronology that we used to date the pine material was a seasonally resolved, composite longleaf pine chronology spanning the period 1499-2013. This chronology includes living material and remnant stump wood from the DeSoto National Forest in southern Mississippi [32]; longleaf pine material from the Amos Deason House in Ellisville, Mississippi [12]; and longleaf pine coffin wood from the Asylum Hill cemetery in Jackson, Mississippi [33] (Figure 4). All six parlor beams were sampled from the attic were tulip poplar, but unfortunately, we were unable to obtain a publicly available reference chronology suitable for cross-dating. The nearest available tulip poplar reference chronology was located in the Southern Appalachian Mountains of northern Georgia, where different climate/growing conditions exist. 


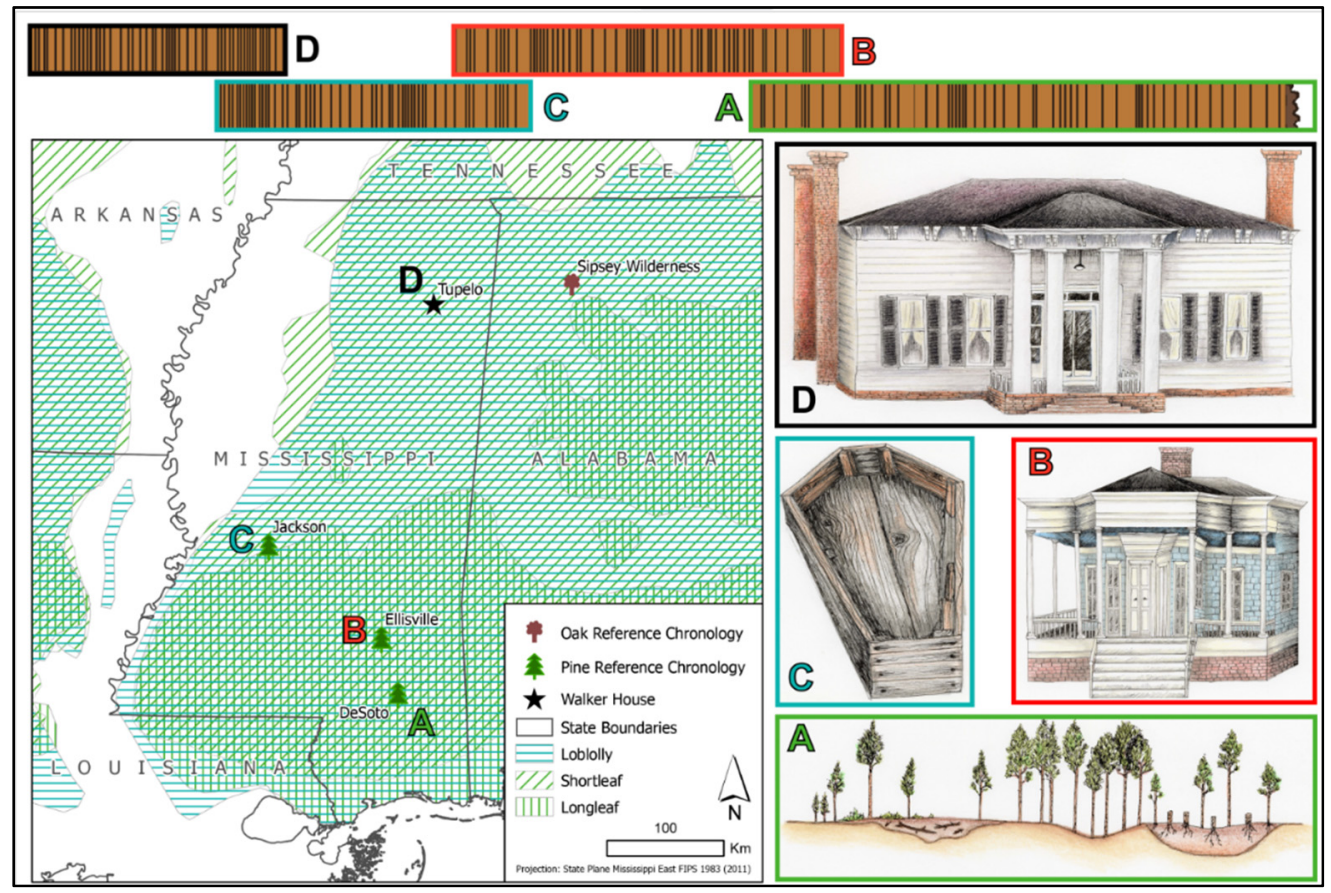

Figure 4. Map of the Walker House study site (star; D), and the locations/illustrations for material that contributed to the cross-dating and development of the longleaf pine latewood reference chronology (points A-C $[12,32,33]$ ). The longleaf pine chronology is comprised of living trees and remnant stumps (A; [32]), material extracted from the Deason House in Ellisville, MS (B; [13]), coffin material escavated near Jackson, MS (C; [33]), and material extracted from the Walker House (D; this study). This map also shows the historic range of longleaf pine (vertical hachures), shortleaf pine (horizontal hachures), and loblolly pine (cross hachures) [34].

\subsection{Statistical Cross-Dating}

The 16 attic pine samples produced a high-quality, 194-year chronology (Table 1) that we dated against the composite longleaf pine reference chronology. After using time-segmented correlation analysis, the Walker House latewood attic pine chronology was anchored against the longleaf pine latewood reference chronology during the period 1541-1734 ( $r=0.52, t=8.43, p<0.0001)$ (Figure 5). Individually, each dated sample was strongly correlated against the reference chronology, with correlation coefficients ranging from 0.36 (IMS1) to 0.75 (DH3), all of which were significant at $p<0.01-0.0001$. Of the 16 dated samples, we determined harvest dates for 14 samples. After visually inspecting the outer portions of the attic pine samples, we determined that the 14 samples that contained the outermost growth ring were harvested during the late spring/early summer of 1734 . This season of felling is based on the presence of a partial outermost growth ring that dates to 1734 . The 1734 ring comprises a thick band of earlywood cells (spring growth) and lacks latewood cell growth, which can initiate as early as June [35].

The six poplar samples from the attic produced a 51-year chronology with an average series length of 35 years (Table 1). Only one of the six samples contained the outer year of growth; however, four of the samples were within five years of the outermost cross-dated year. Though we were able to cross-date the poplar samples to each other (Table 1), we were unable to locate a suitable reference chronology to precision date this material. 
Table 1. Diagnostics and dating statistics for each of the Walker House chronologies.

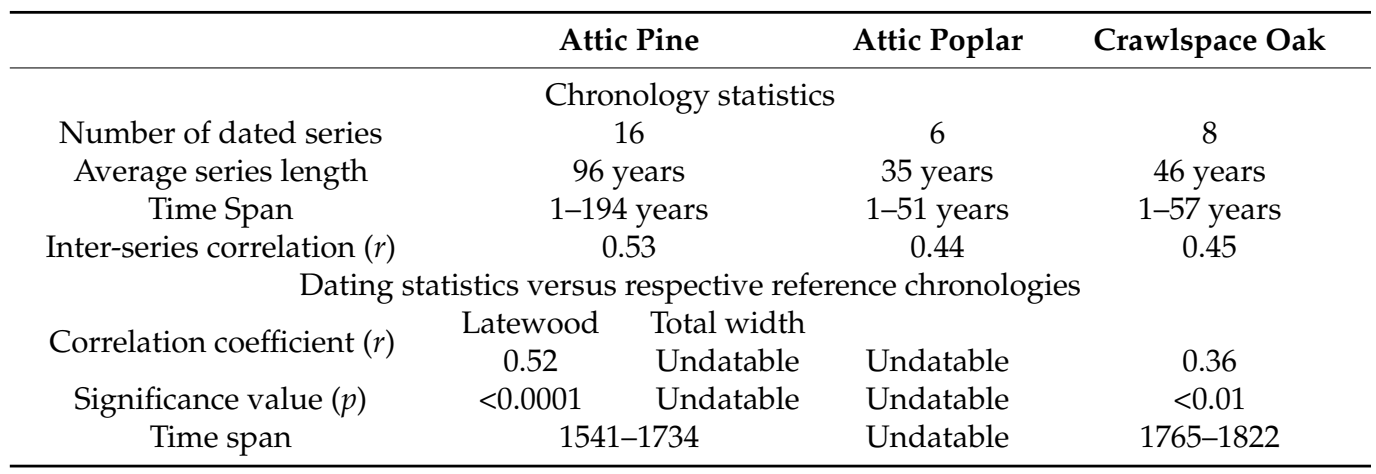

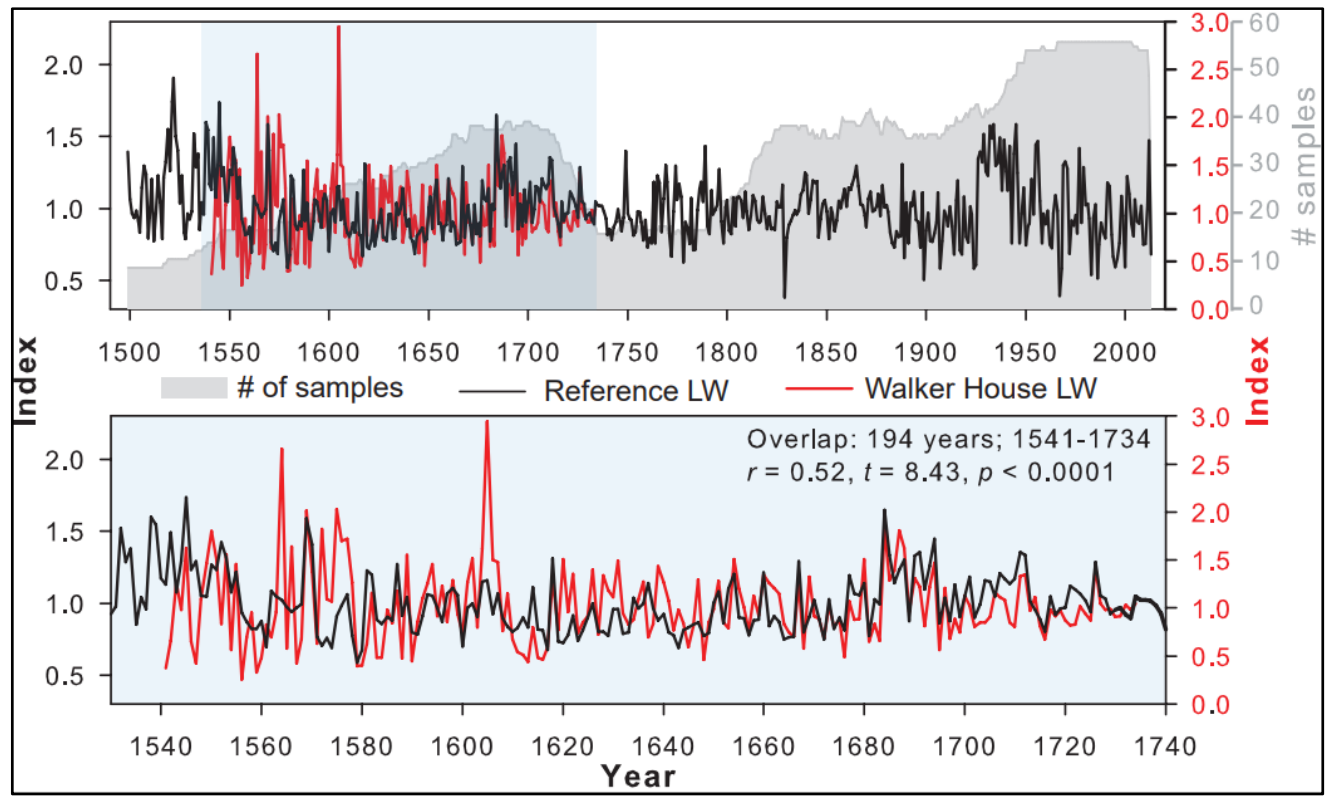

Figure 5. The Walker House latewood-width (LW) chronology (red) plotted with the longleaf pine LW reference chronology (black). Top panel shows the temporal placement of the Walker House chronology against the entire reference chronology, and the bottom panel shows a zoomed inset. The Walker House chronology is anchored in time against the reference chronology from 1541 to 1734 ( $n=194$ years, $r=0.52, t=8.43, p<0.0001)$.

The crawlspace oak samples produced a 57-year chronology (Table 1) that we dated against the Sipsey Wilderness white oak reference chronology. Our best dating match occurred when the outer year was placed at $1822(r=0.36, t=2.83, p<0.01)$, spanning 1765-1822. The relationship between the Walker House crawlspace oak chronology and the Sipsey Wilderness white oak reference chronology is convincing statistically and graphically (Figure 6). Five of the eight oak samples that contained the outer year of 1822 included earlywood vessels and latewood growth. We hypothesize that these samples were harvested late in the growing season of 1822 or before vessel growth started in early 1823. Further information on the sampling location for all chronologies can be found in Appendix A. 


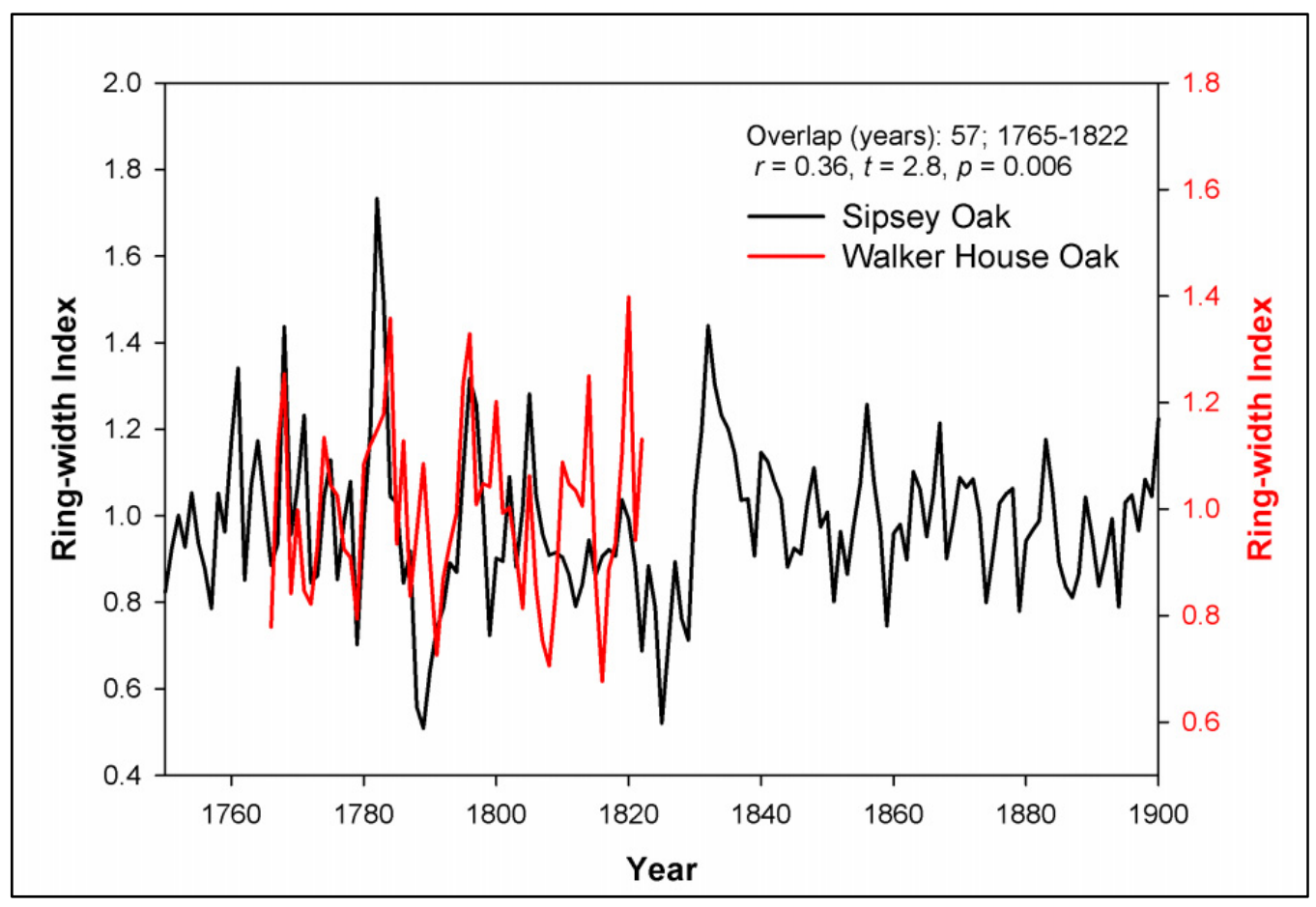

Figure 6. The Walker House oak chronology (red) plotted with the white oak reference chronology from the Sipsey Wilderness (black). The Walker House oak chronology is anchored in time against the reference chronology from 1765 to 1822 ( $n=57$ years, $r=0.36, t=2.80, p<0.01$ ).

\section{Discussion}

We were unable to confirm our two hypotheses that the hand-hewn attic timbers were salvaged from the ca. 1814 Council House and that the milled timbers would precisely date the Walker construction to the early 1850s. However, we made an entirely unexpected discovery; the pine timbers we thought were felled and milled for the 1850s-era Walker House were in fact salvaged from a structure built in 1734 . The three published dendroarchaeology studies in the Gulf Coastal Plain have revealed construction dates of 1835 [12], 1762 [14], and 1757 [13]. While we do not assert that the Walker House was constructed in 1734 , the dating of the latewood attic pine chronology to 1541-1734 is unequivocal, making it the oldest dendrochronology-dated material in the Gulf Coastal Plain.

Our use of latewood for cross-dating the pine samples is supported by a growing body of literature that indicates a high degree of interannual variability in longleaf pine latewood, making this growth metric ideal for most dendrochronological applications. For example, studies have found that longleaf pine latewood ring width produces the strongest climate-growth relationships [33-39]. Most recently, Stambaugh et al. [30] and Soule et al. [29] exclusively used latewood ring-growth when cross-dating longleaf pine, and Soule et al. [29] advocates for latewood cross-dating for all southeastern pine (e.g., Pinus echniata Mill.) with similar growth patterns. The only known use of longleaf pine latewood cross-dating for dendroarchaeology is by Summers [11], who used a montane longleaf pine latewood reference chronology to date oak timbers from a historic farmhouse in central North Carolina. Our findings support the pre-existing literature describing the robust variability of longleaf pine latewood, and the utility for using this growth metric for the precision cross-dating of pine timbers in the southeastern US.

The assemblage of the composite longleaf pine reference chronology from multiple sources was necessary to date the pine timbers in the Walker House, and our results highlight two important features regarding its use. First, Tupelo, Mississippi, exists outside the formal longleaf pine range [40], and we suspect the pine timbers are either loblolly pine (Pinus taeda L.) or shortleaf pine (Figure 4). Fortunately, these pine species have similar climate-growth statistics as longleaf pine [41-43] and therefore have been shown to cross- 
date due to concurrent growth conditions. Second, few old-growth pine stands exist in the state of Mississippi, and the closest publicly available pine reference chronology is located in the Ridge and Valley region of northwestern Alabama. The lack of old-growth pine forests in Mississippi due to centuries of exploitative logging [44] has led to a reduction in longleaf pine from $>85 \%$ spatial coverage to $<10 \%$ [45]. The scarcity of living pine material, as well as the lack of old-growth stands, led us to develop the composite longleaf pine chronology, and without this chronology, we would not have been able to cross-date the attic pine material to the early 18th century.

We dated the crawlspace oak chronology to 1822 , yet we have less confidence in this date for the following reasons. First, the chronology was small $(n=8)$, produced from young trees (1/4 of samples contained near-pith curvature), and lacked sample depth (57 years). The Sipsey Wilderness reference chronology had an average series length of 239 years, indicating we were cross-dating young material with old-growth trees. Second, the correlation between the crawlspace oak chronology and the reference chronology was statistically significant, yet weak $(r=0.36, t=2.83, p<0.01)$, especially in relation to the average series intercorrelation for all samples in the reference chronology, which was $r=0.61, p<0.01$. Even though we assigned 1822 as the most probable felling date, we recognize the lack of strong statistical evidence supporting this assertion. The year 1822 was the most accurate felling date based on our analysis, and we believe that our dating statistics will improve once new multi-century (ex. 300 year) oak reference chronologies become available in the northern Gulf Coastal Plain.

\section{Conclusions}

We generated statistical and graphical evidence that indicated the Walker House attic's pine timbers were harvested in 1734, and the crawlspace oak timbers were likely harvested in 1822. To our knowledge, the Walker House is the first structure in the northern Gulf Coastal Plain region to undergo dendroarcheological investigation. Our findings highlight the need for additional dated structures and multi-century reference chronologies in this region. As the network of dated material expands, future dendrochronology studies will benefit from this enhanced spatial and temporal coverage of tree-ring data.

We advocate for cross-dating using latewood ring width when working with southern pine species, as our results were successful when cross-dating latewood ring width across the state of Mississippi. We have demonstrated the use of precision dating archaeological pine material using latewood ring width, and our research contributes to the growing body of literature that suggests this growth metric is superior for longleaf pine. Our assemblage of the composite longleaf pine reference chronology served as the only means to date the early 18th century material, and without its use, the attic pine chronology would not have been dateable. We attribute the successes of this project to the exceptional ring-growth characteristics of longleaf pine and to our colleagues who have demonstrated its many applications across the southeastern US.

Author Contributions: Conceptualization, R.T.D., T.W.P., G.L.H. and D.H.H.; methodology, R.T.D., T.W.P., G.L.H. and D.H.H.; data collection, T.W.P., G.L.H., D.H.H., D.J.K., R.T.D., A.L.C., A.C.C. and I.M.S.; formal analysis, G.L.H., T.W.P. and D.H.H.; writing-original draft preparation, T.W.P., G.L.H., D.H.H. and R.T.D.; writing-review and editing, T.W.P., G.L.H., D.H.H., R.T.D., D.J.K., K.J.H., A.L.C., A.C.C. and I.M.S.; funding acquisition, R.T.D. All authors have read and agreed to the published version of the manuscript.

Funding: This research was funded by the homeowner, Raymond Doherty.

Conflicts of Interest: The authors declare no conflict of interest. 


\section{Appendix A}

\begin{tabular}{|c|c|c|}
\hline \multicolumn{3}{|c|}{ Walker House Attic Poplar Chronology Sample Locations } \\
\hline Core ID & Location as identified from within the structure & Outer ring type \\
\hline DK4 & - & $\mathrm{N}$ \\
\hline DK5 & IGs | Eave girt (south) & $\mathrm{O}$ \\
\hline IS2 & IGw I Eave girt (west) & $\mathrm{N}$ \\
\hline $\mathrm{DH} 4$ & IGs | Eave girt (south) & $\mathrm{N}$ \\
\hline DH7 & DGn | Eave girt (north) & $X$ \\
\hline DH8 & F/G I Wall girt & $\mathrm{N}$ \\
\hline
\end{tabular}

Code for outer ring type: $\mathrm{O}=$ outer ring present, $\mathrm{N}=$ outer ring near to harvest date $(<5$ years missing), $\mathrm{X}=$ Harvest date could not be determined.

\begin{tabular}{lll}
\hline \multicolumn{2}{l}{ Walker House Crawlspace Oak Chronology Sample Locations } \\
\hline Core ID & Location as identified from within the structure & Outer ring type \\
CSEF6 & - & $\mathrm{O}$ \\
CSS3 & - & $\mathrm{O}$ \\
CSBeam & - & $\mathrm{O}$ \\
CSES4 & - & $\mathrm{O}$ \\
CSF3 & - & $\mathrm{O}$ \\
CSF5 B & - & $\mathrm{N}$ \\
CSN5D & - & $\mathrm{N}$ \\
CSN5A & - & $\mathrm{N}$ \\
\hline
\end{tabular}

Code for outer ring type: $\mathrm{O}=$ outer ring present, $\mathrm{N}=$ outer ring near to Harvest date $(<5$ years missing).

\begin{tabular}{|c|c|c|}
\hline \multicolumn{3}{|c|}{ Walker House Attic Pine Chronology Sample Locations } \\
\hline Core ID & Location as identified from within the structure & Outer ring type \\
\hline DK2 & G6 I Extension joist & $\mathrm{O}$ \\
\hline DH2 & GL / Lookout & B \\
\hline GH1 & EL / Lookout & $\mathrm{O}$ \\
\hline GH2A and B & E3 | Extension joist & $\mathrm{O}$ \\
\hline GH4 & F4 I Extension joist & $\mathrm{O}$ \\
\hline AC2 & GL I Lookout & $\mathrm{O}$ \\
\hline $\mathrm{AC} 1$ & EL | Lookout & $\mathrm{O}$ \\
\hline DK1 & DL I Lookout & $\mathrm{O}$ \\
\hline DK3 & IL | Lookout & $\mathrm{O}$ \\
\hline GH3 & DL / Lookout & $\mathrm{O}$ \\
\hline DH3NE & BHR | Hip rafter & $\mathrm{O}$ \\
\hline ACC1 & - & $\mathrm{N}$ \\
\hline DH5 & RF3 | Rafter & $\mathrm{N}$ \\
\hline CSWall & Crawlspace middle of structure & $\mathrm{N}$ \\
\hline DH1 & G6 I Extension joist & $\mathrm{x}$ \\
\hline
\end{tabular}

Code for outer ring type: $\mathrm{B}=$ bark present, $\mathrm{O}=$ outer ring present, $\mathrm{N}=$ outer ring near to harvest date $(<5$ years missing), $X=$ Harvest date could not be determined.

\section{References}

1. Speer, J.H. Fundamentals of Tree-Ring Research; University of Arizona Press: Tucson, AZ, USA, 2010.

2. Garland, N.A.; Grissino-Mayer, H.D.; Deagan, K.; Harley, G.L.; Waters, G. Dendrochronological Dating of Wood from the Fountain of Youth Park Archaeological Site (8SJ31), St. Augustine, Florida, USA. Tree Ring Res. 2012, 68, 69-78. [CrossRef]

3. Therrell, M.D.; Stahle, D.W. Tree-ring Dating of an Arkansas Antebellum Plantation House. Tree Ring Res. 2012, 68, 59-67. [CrossRef]

4. Stachowiak, L.A.; Schneider, E.A.; Rochner, M.L.; Collins, S.A.; Swiney, C.P.; Grissino-Mayer, H.D.; Mckenzie, T.G. Dendrochronological Dating of the Historic Mckenzie Home, Meigs County, Tennessee, USA. Tree Ring Res. 2014, 70, 31-39. [CrossRef]

5. Stachowiak, L.A.; Schneider, E.A.; Rochner, M.L.; Collins, S.A.; Grissino-Mayer, H.D. Dendrochronological Dating of Historic Log Cabins on the Belle Meade Plantation, Davidson County, Tennessee, USA. Veg. Hist. Archaeobotany 2016, 25, 105-115. [CrossRef]

6. Cockrell, S.W.; de Graauw, K.K.; Ziegler, A.M.; Hessl, A.E. Precision dating of Cook's Mill, a Civil War era structure in West Virginia. Dendrochronologia 2017, 43, 20-26. [CrossRef] 
7. DeWeese, G.G.; Grissino-Mayer, H.D.; Bishop, W.J. The historical dendroarchaeology of the Green Hotel, Cave Spring, Georgia, USA. Dendrochronologia 2017, 43, 74-80. [CrossRef]

8. Druckenbrod, D.L.; Stachowiak, L.A.; Schneider, E.A. Dendrochronological dating of the Graves Mill grist mill, Madison County, Virginia, USA. Dendrochronologia 2017, 43, 27-32. [CrossRef]

9. Rochner, M.L.; Van de Gevel, S.; Spond, M.D.; Grissino-Mayer, H.D. Using Dendrochronology to Investigate the Historical and Educational Value of two Log Structures at Bear Paw State Natural Area, North Carolina, USA. Tree Ring Res. 2017, 73, 136-148. [CrossRef]

10. Therrell, M.D.; Mozayen, B.S.; Gage, M.D. The search for Fort Armstrong: Dendroarchaeology of the Williamson "Snow Hill” Plantation, Cherokee County, Alabama, USA. Dendrochronologia 2017, 43, 59-65. [CrossRef]

11. Summers, J.C. Dendroarchaeology and the Dating of Historic Farm Buildings on the Summers' Farm, Summerfield, NC. Master's Thesis, Department of Geography, Environment, and Sustainability, University of North Carolina, Greensboro, NC, USA, 2019; p. 33.

12. Harley, G.L.; Maxwell, J.T.; Holt, D.H.; Speagle, C.B. Construction history of the Deason House, Jones County, Mississippi. Dendrochronologia 2017, 43, 50-58. [CrossRef]

13. Harley, G.L.; Maxwell, J.T.; Oliver, J.S.; Holt, D.H.; Bowman, J.; Sokolosky-Wixon, M. Precision dating and cultural history of the La Pointe-Krebs House (22JA526), Pascagoula, Mississippi, USA. J. Archaeol. Sci. Rep. 2018, 20, 87-96. [CrossRef]

14. Tucker, C.S.; Harley, G.L.; Oliver, J.S.; Baird, D. Taxodium distichum (baldcypress) growth rings reveal origins of an 18th century Jesuit plantation, New Orleans, Louisiana, USA. Dendrochronologia 2019, 53, 95-103. [CrossRef]

15. Feng, G.; Cobb, S.; Abdo, Z.; Fisher, D.K.; Ouyang, Y.; Adeli, A.; Jenkins, J.N. Trend analysis and forecast of precipitation, reference evapotranspiration, and rainfall deficit in the Blackland Prairie of Eastern Mississippi. J. Appl. Meteorol. Climatol. 2016, 55, 1425-1439. [CrossRef]

16. PRISM Climate Group. 30-Year Normals. 2021. Available online: http:/ / prism.oregonstate.edu (accessed on 15 February 2021).

17. Suiter, D.R.; Jones, S.C.; Forschler, B.T. Biology of Subterranean Termites in the Eastern United States. Bulletin 1209; University of Georgia: Athens, GA, 2012. Available online: http:/ / hdl.handle.net/10724/12156 (accessed on 15 March 2021).

18. Zhao, S.; Pederson, N.; D’Orangeville, L.; HilleRisLambers, J.; Boose, E.; Penone, C.; Bauer, B.; Jiang, Y.; Manzanedo, R.D. The international tree-ring data bank (ITRDB) revisited: Data availability and global ecological representativity. J. Biogeogr. 2019, 46, 355-368. [CrossRef]

19. Doherty, R. The Colbert-Walker Site: History and Archaeology of a Chickasaw Home, Council House, and Travelers' Stand. Master's Thesis (undefended), Department of Anthropology, University of Mississippi, Oxford, MI, USA, 2021.

20. Edwards, J.D.; Wells, T. Historic Louisiana Nails: Aids to the Dating of Old Buildings; Geosciences Publications, Department of Geography and Anthropology, Louisiana State University: Baton Rouge, LA, USA, 1993.

21. Works Progress Administration. Historical Records Survey (WPA Files); RG60, WPA File No. 334. Lee County, Indians, Source Material, Historical Research, Chapter VI, Indians; Washington, DC, USA, 1938. Available online: https:/ / www.archives.gov / research/guide-fed-records/groups/069.html (accessed on 15 March 2021).

22. Shallus, F. Mississippi Territory (Map); Courtesy of Birmingham Public Library Cartography Collection; M. Carey and Son: Philadelphia, PA, USA, 1814.

23. Larsson, L. CooRecorder and Cdendro Programs of the CooRecorder/Cdendropackage Version 9.1. Saltsjöbaden, Sweeden, 2013.

24. Holmes, R.L. Computer-assisted quality control in tree-ring dating and measurement. Tree Ring Bull. 1983, 43, 69-78. Available online: http: / / hdl.handle.net/10150/261223 (accessed on 15 March 2021).

25. Cook, E.R. A Time Series Analysis Approach to Tree Ring Standardization. Ph.D. Dissertation, The University of Arizona, Tucson, AZ, USA, 1985; p. 171.

26. Cook, E.R.; Holmes, R.L. Guide for computer program ARSTAN. In The International Tree Ring Data Bank Program Library Version 2.0 User's Manual; Grissino-Mayer, H.D., Holmes, R.L., Fritts, H.C., Eds.; University of Arizona: Tucson, AZ, USA, 1996; pp. 75-87.

27. Hoadley, R.B. Identifying Wood: Accurate Results with Simple Tools; Taunton Press: Newtown, CT, USA, 1990.

28. National Oceanic and Atmospheric Administration. The International Tree-Ring Data Bank. 2021. Available online: https: //www.ncdc.noaa.gov/data-access/paleoclimatology-data/datasets/tree-ring (accessed on 15 February 2020).

29. Soulé, P.T.; Knapp, P.A.; Maxwell, J.T.; Mitchell, T.J. A comparison of the climate response of longleaf pine (Pinus palustris Mill.) trees among standardized measures of earlywood, latewood, adjusted latewood, and totalwood radial growth. Trees Struct. Funct. 2021, 1-10. [CrossRef]

30. Stambaugh, M.C.; Bigelow, S.W.; Abadir, E.R. Linkages between forest growth, climate, and agricultural production are revealed through analysis of seasonally-partitioned longleaf pine (Pinus palustris Mill.) tree rings. Dendrochronologia 2021, 65, 125801. [CrossRef]

31. Cook, E.R. NOAA/WDS Paleoclimatology-Cook-Sipsey Wilderness-QUAL-ITRDB AL001. [Totalwidth]. NOAA National Centers for Environmental Information. 2002. Available online: https://doi.org/10.25921/wwtp-9h82 (accessed on 15 April 2020).

32. White, C.R.; Harley, G.L. Historical fire in longleaf pine (Pinus palustris) forests of south Mississippi and its relation to land use and climate. Ecosphere 2016, 7, e01458. [CrossRef] 
33. Herrmann, N.P.; Davenport, M.L.; Plemons, A.M.; Harley, G.L.; Shaefer, A.D.; Zuckerman, M.K.; Trask, W.R. Historical Bioarchaeology and DVI: Data Integration of the Mississippi State Asylum Burial Sample and Archival Records. Am. J. Phys. Anthropol. 2016, 162, 215-216.

34. Little, E.L., Jr. Atlas of United States Trees. Volume 1. Conifers and Important Hardwoods; Misc. Publ. 1146; Department of Agriculture, Forest Service: Washington, DC, USA, 1971.

35. Rother, M.T.; Huffman, J.M.; Harley, G.L.; Platt, W.J.; Jones, N.; Robertson, K.M.; Orzell, S.L. Cambial phenology informs tree-ring analysis of fire seasonality in Coastal Plain pine savannas. Fire Ecol. 2018, 14, 164-185. [CrossRef]

36. Henderson, J.P.; Grissino-Mayer, H.D.; Van De Gevel, S.L.; Hart, J.L. The historical dendroarchaeology of the Hoskins House, Tannenbaum Historic Park, Greensboro, North Carolina, USA. Tree Ring Res. 2009, 65, 37-45. [CrossRef]

37. Knapp, P.A.; Maxwell, J.T.; Soulé, P.T. Tropical cyclone rainfall variability in coastal North Carolina derived from longleaf pine (Pinus palustris Mill.): AD 1771-2014. Clim. Chang. 2016, 135, 311-323. [CrossRef]

38. Patterson, T.W.; Cummings, L.W.; Knapp, P.A. Longleaf pine (Pinus palustris Mill.) morphology and climate/growth responses along a physiographic gradient in North Carolina. Prof. Geogr. 2016, 68, 238-248. [CrossRef]

39. Mitchell, T.J.; Knapp, P.A.; Patterson, T.W. The importance of infrequent, high-intensity rainfall events for longleaf pine (Pinus palustris Mill.) radial growth and implications for dendroclimatic research. Trees For. People 2020, 1, 100009. [CrossRef]

40. Frost, C. History and Future of the Longleaf Pine Ecosystem. In The Longleaf Pine Ecosystem; Jose, S., Jokela, E.J., Miller, D.L., Eds.; Springer Series on Environmental Management; Springer: New York, NY, USA, 2007. [CrossRef]

41. Friend, A.L.; Hafley, W.L. Climatic limitations to growth in loblolly and shortleaf pine (Pinus taeda and P. echinata): A dendroclimatological approach. For. Ecol. Manag. 1989, 26, 113-122. [CrossRef]

42. Samuelson, L.J.; Eberhardt, T.L.; Bartkowiak, S.M.; Johnsen, K.H. Relationships between climate, radial growth and wood properties of mature loblolly pine in Hawaii and a northern and southern site in the southeastern United States. For. Ecol. Manag. 2013, 310, 786-795. [CrossRef]

43. Watkins, K.E.; Patterson, T.W.; Knapp, P.A. Investigating the climatic sensitivity of shortleaf pine on a southeastern US college campus. Southeast. Geogr. 2018, 58, 146-163. [CrossRef]

44. Hickman, N. Mississippi Harvest: Lumbering in the Longleaf Pine Belt, 1840-1915; University Press of Mississippi: Jackson, MS, USA, 1962.

45. Hanberry, B.B.; Coursey, K.; Kush, J.S. Structure and composition of historical longleaf pine ecosystems in Mississippi, USA. Hum. Ecol. 2018, 46, 241-248. [CrossRef] 